\title{
Phytoprotection
}

\section{Note on the effect of low temperatures on the survival of adults and larvae of the American black flour beetle, Tribolium audax}

\section{P.S. Barker}

Volume 72, numéro 2, 1991

URI : https://id.erudit.org/iderudit/706006ar

DOI : https://doi.org/10.7202/706006ar

Aller au sommaire du numéro

Éditeur(s)

Société de protection des plantes du Québec (SPPQ)l

ISSN

0031-9511 (imprimé)

1710-1603 (numérique)

Découvrir la revue

Citer cet article

Barker, P. (1991). Note on the effect of low temperatures on the survival of adults and larvae of the American black flour beetle, Tribolium audax.

Phytoprotection, 72(2), 77-80. https://doi.org/10.7202/706006ar
Résumé de l'article

De la farine contenant des larves et des adultes du Tribolium audax a été exposée pendant $1,2,4,8,12,17,24$ et 45 semaines à des températures de $-5,3$ et $10^{\circ} \mathrm{C}$. De la farine contenant des insectes a aussi été exposé à une température de $-15^{\circ} \mathrm{C}$ pendant $1,3,5,7,8,13$ et 15 jours. On a observé une réduction de la survie des larves et des adultes avec une augmentation de la durée d'exposition à toutes les températures. Des adultes et des larves ont survécu pendant 45 semaines à -5 et $10^{\circ} \mathrm{C}$, mais seulement les larves ont survécu pendant 45 semaines à $3^{\circ} \mathrm{C}$. Les valeurs de TL50 et de TL95 ont été calculées pour chaque température. Aucun insecte n'a survécu pendant 15 jours à $-15^{\circ} \mathrm{C}$. L'utilisation du froid pour réprimer le $T$. audax a peu de chances de réussir. 


\title{
Note on the effect of low temperatures on the survival of adults and larvae of the American black flour beetle, Tribolium audax
}

\author{
Philip S. Barker \\ Agriculture Canada Research Station, 195 Dafoe Road, Winnipeg, Manitoba, \\ Canada, R3T 2M9. Contribution $N^{\circ} 1439$.
}

(Received 1990-11-01; accepted 1991-05-16)

\begin{abstract}
Flour infested with adults and late-instar larvae of the American black flour beetle, Tribolium audax, was held for 1, $2,4,8,12,17,24$, and 45 weeks at each of the following temperatures: $-5,3$, and $10^{\circ} \mathrm{C}$, and for $1,3,5,7,8,13$, and 15 days at $-15^{\circ} \mathrm{C}$. Survival of the adults and larvae declined with increasing time of exposure at each temperature. Some adults and larvae survived 45 weeks at -5 and $10^{\circ} \mathrm{C}$, but only larvae survived 45 weeks of exposure at $3^{\circ} \mathrm{C}$. The $\mathrm{LT}_{50}$ and $\mathrm{LT}_{95}$ were determined for each temperature. No insects survived an exposure of 15 days at $-15^{\circ} \mathrm{C}$. Low temperatures are unlikely to be useful as a practical means for control of $T$. audax.
\end{abstract}

Barker, P. S. 1991. Note on the effect of low temperatures on the survival of adults and larvae of the American black flour beetle, Tribolium audax. PHYTOPROTECTION 72: 77-80.

De la farine contenant des larves et des adultes du Tribolium audax a été exposée pendant 1, 2, 4, 8, 12, 17, 24 et 45 semaines à des temperatures de $-5,3$ et $10^{\circ} \mathrm{C}$. De la farine contenant des insectes a aussi été exposé à une température de $-15^{\circ} \mathrm{C}$ pendant $1,3,5,7,8,13$ et 15 jours. On a observé une réduction de la survie des larves et des adultes avec une augmentation de la durée d'exposition à toutes les températures. Des adultes et des larves ont survécu pendant 45 semaines à -5 et $10^{\circ} \mathrm{C}$, mais seulement les larves ont survécu pendant 45 semaines à $3^{\circ} \mathrm{C}$. Les valeurs de $\mathrm{TL}_{50}$ et de $\mathrm{TL}_{95}$ ont été calculées pour chaque température. Aucun insecte n'a survécu pendant 15 jours à $-15^{\circ} \mathrm{C}$. L'utilisation du froid pour réprimer le $T$. audax a peu de chances de réussir.

One means of prevention of spoilage of stored grain and its infestation by mites and insects is by cooling and drying the bulks of grain (Loschiavo et al. 1983). Because grain can have an insulating effect, the centres of grain bulks do not cool as rapidly as the periphery of the bulks, thus offering insects and mites a niche where they can survive long periods of cold temperatures. Smith (1970) found that the centre of a $27.5 \mathrm{t}$ bulk of wheat reached a minimum temperature of $-7^{\circ} \mathrm{C}$ during a Winnipeg winter, although the average temperature for January is $-18.3^{\circ} \mathrm{C}$ (Anonymous 1985). A means of reducing the insulating effect of grain is to move and mix (transfer) the grain during periods of cold weather. Watters (1963) has shown that the average temperature of a $4.5 \mathrm{t}$ bulk of wheat was reduced from 11.8 to $5.9^{\circ} \mathrm{C}$ in 2 days after transfer while ambient temperatures ranged from -6.6 to $4.4^{\circ} \mathrm{C}$. Aeration systems are also used to cool grain by forcing cold ambient air through the grain mass (Hall 1980).

The American black flour beetle, Tribolium audax Halstead (Coleoptera: Tenebrionidae), has been found in grain residues in granaries in the Prairie provinces (Smith and Barker 1987), but not in bulks of grain (Madrid et al. 1990). Bousquet (1990) mentions that it is also found in flour and feed mills, warehouses, boxcars and retail stores. Its tolerance to cold has not been determined.

The objective of this work was to ascertain the effect of low temperatures on the survival of non-acclimatized adults and larvae of $T$. audax.

Tribolium audax were collected from a farm in Manitoba in 1983. Tribolium audax cultures were grown in flour fortified with brewer's yeast $(95: 5, \mathrm{v}: \mathrm{v})$. The cultures in the flour medium were kept in 4-L glass jars which had $9 \mathrm{~cm}$ external diameter mouths. The mouths of the jars were covered with $9 \mathrm{~cm}$ diameter filter paper disks that were sealed to the glass with paraffin wax. The $T$. audax cultures were maintained at $25^{\circ} \mathrm{C}$ and $60-70 \%$ RH.

Ten adults ( 2 to 3 weeks old) and 10 larvae $\left(3^{\text {rd }}\right.$ or $4^{\text {th }}$ instars) were placed in each of 200 vials. Young adult insects were used since some tests ran for 45 weeks. The insects were not acclimatized. The vials contained $5 \mathrm{~g}$ of flour fortified with brewer's yeast (95:5, v:v). Perforated caps were placed on each vial. 
Forty vials with their insects were placed in each of five desiccators. A saturated salt $(\mathrm{NaCl})$ solution was placed in the bottom of each desiccator to maintain a relative humidity in the desiccator of $75 \pm 5 \%$ at room temperature (Solomon 1951). Relative humidity was verified with a Vaisala Humidity and Temperature indicator (HMI - 32). One desiccator with its vials was placed at each of five temperatures: $-15,-5,3,10$, and $20 \pm 0.5^{\circ} \mathrm{C}$. Five vials were withdrawn from each desiccator placed at $-5,3,10$, and $20^{\circ} \mathrm{C}$ at the end of $1,2,4,8,12$, 17, 24, and 45 weeks. Five vials were drawn from the desiccator at $-15^{\circ} \mathrm{C}$ at $1,3,5,7,8,13$, and 15 days. The insects were sifted from the flour, counted, and then returned with their flour to the original vials and placed at $25^{\circ} \mathrm{C}$ and $60-70 \% \mathrm{RH}$ and live insects counted again $24 \mathrm{~h}$ later. Dead insects showed no movement under a warm lamp. The insects from the desiccator at $20^{\circ} \mathrm{C}$ were used as controls.

Probit analyses, tests for parallelism, and potency ratios were performed on the data (Bliss 1935; Finney 1971). Abbott's (1925) formula was used to account for natural mortality in the controls. The heterogeneity factor was the chi-square divided by (n-2) degrees of freedom. The times required to obtain 50 and 95\% mortality $\left(\mathrm{LT}_{50}\right.$ and $\mathrm{LT}_{95}$ ) of the larvae and adults of T. audax at $-5,3$, and $10^{\circ} \mathrm{C}$, and of larvae at $-15^{\circ} \mathrm{C}$ were determined.

All adults of T. audax were dead at the end of 5 days at $-15^{\circ} \mathrm{C}$. Larvae were more tolerant than the adults to $-15^{\circ} \mathrm{C}$, but all larvae had died after 15 days. Larval mortality started to rise rapidly from the $4^{\text {th }}$ week onwards at $-5^{\circ} \mathrm{C}$, and from the $8^{\text {th }}$ week onwards at 3 and $10^{\circ} \mathrm{C}$.
Adult mortality started to rise steeply from the $8^{\text {th }}$ week onwards at $-5,3$, and $10^{\circ} \mathrm{C}$. Mortality of larvae and adults increased steadily with time at $-5,3$, and $10^{\circ} \mathrm{C}$. There was more than $75 \%$ mortality of larvae and adults at these temperatures by the end of 45 weeks and complete kill was only obtained for adults exposed to $3^{\circ} \mathrm{C}$ for 45 weeks. This level of tolerance to cold by non-acclimatized insects would allow the species to live through winters in most parts of the Canadian Prairies if the insects could find sheltered places such as grain bulks.

There was a progressive increase in the median lethal times $\left(\mathrm{LT}_{50}\right)$ for the larvae as temperature increased from -15 to $10^{\circ} \mathrm{C}(\mathrm{Ta}$ ble 1). The upper limits of the $95 \%$ confidence intervals of the $\mathrm{LT}_{95}$ indicated that some individuals can survive for a very long time (more than 1 year) at $-5,3$, and $10^{\circ} \mathrm{C}$. Some larvae survived 45 weeks at $-5^{\circ} \mathrm{C}$, even though the $\mathrm{LT}_{95}$ was 38.2 weeks. This survival was reflected in the $95 \%$ confidence interval of the $\mathrm{LT}_{95}$, which was 69.6 weeks at $-5^{\circ} \mathrm{C}$.

The $\mathrm{LT}_{50}$ obtained for adults at $-5^{\circ} \mathrm{C}$ was higher than the $\mathrm{LT}_{50}$ 's obtained at 3 and $10^{\circ} \mathrm{C}$ (Table 1). The adults which survived $-5^{\circ} \mathrm{C}$ produced offspring.

To compare results obtained at the different temperatures, it was first necessary to establish whether or not the log-dosage probit-mortality lines were parallel, and if so, then calculate the relative magnitudes of the effects of the treatments (relative potency) at the $50 \%$ mortality level $\left(\mathrm{LT}_{50}\right)$. The tests for parallelism showed that heterogeneity was

Table 1. Effect of time exposure at four temperatures on the mortality of larvae and adults of Triboliam audax

\begin{tabular}{|c|c|c|c|c|c|c|c|}
\hline \multirow[b]{2}{*}{$\begin{array}{l}\text { Temperature } \\
\qquad\left({ }^{\circ} \mathrm{C}\right)\end{array}$} & \multirow[b]{2}{*}{$\begin{array}{c}\mathrm{LT}_{50} \\
\text { (weeks) }\end{array}$} & \multirow{2}{*}{$\begin{array}{c}\text { Confidence } \\
\text { interval } \\
(95 \%)\end{array}$} & \multirow[b]{2}{*}{$\begin{array}{c}\mathrm{LT}_{95} \\
\text { (weeks) }\end{array}$} & \multirow{2}{*}{$\begin{array}{c}\text { Confidence } \\
\text { interval } \\
(95 \%)\end{array}$} & \multicolumn{3}{|c|}{ Probit analysis } \\
\hline & & & & & $\begin{array}{l}\text { Heterogeneity } \\
\text { factor }\end{array}$ & Slope & Intercept \\
\hline \multicolumn{8}{|l|}{ Larvae } \\
\hline-15 & 0.5 & $0.37-0.70$ & 1.9 & $1.1-3.2$ & 0.52 & 2.93 & 5.85 \\
\hline-5 & 8.6 & $6.2-11.9$ & 38.2 & $20.9-69.6$ & 1.08 & 2.54 & 2.6 \\
\hline 3 & 15.4 & $11.7-20.3$ & 44.5 & $22.9-86.0$ & 1.01 & 3.57 & 0.74 \\
\hline 10 & 26.8 & $19.0-37.6$ & 88.1 & $37.1-209.1$ & 0.09 & 3.18 & 0.45 \\
\hline \multicolumn{8}{|l|}{ Adults } \\
\hline-5 & 28.3 & $18.5-43.2$ & 78.6 & $22.1-278.5$ & 0.01 & 3.39 & 0.09 \\
\hline 3 & 19.8 & $13.4-29.3$ & 43.4 & $16.8-112.2$ & 1.14 & 4.82 & -1.25 \\
\hline 10 & 18.6 & $14.0-24.6$ & 58.5 & $28.3-120.5$ & 0.16 & 3.30 & 0.79 \\
\hline
\end{tabular}


Table 2. Potency ratios from comparisons of the $\mathrm{LT}_{50}$ obtained from the exposure of larvae and adults of Tribolium audax to different temperatures

\begin{tabular}{ccc}
\hline $\begin{array}{c}\text { Comparison } \\
\text { temperatures }\left({ }^{\circ} \mathrm{C}\right)\end{array}$ & Actual ratio of $\mathrm{LT}_{50}$ & Potency ratio $\begin{array}{c} \pm \text { variance, assuming } \\
\text { parallelism }\end{array}$ \\
\hline $\begin{array}{c}\text { adult/larvae } \\
-5 /-5\end{array}$ & 3.30 & $3.35 \pm 0.005$ \\
$3 / 3$ & 1.28 & $1.36 \pm 0.003$ \\
$10 / 10$ & 0.69 & $0.73 \pm 0.003$ \\
larvae/larvae & & \\
$-5 /-15$ & 16.80 & $17.51 \pm 0.013$ \\
$3 /-15$ & 30.20 & $29.86 \pm 0.009$ \\
$10 /-15$ & 52.50 & $52.89 \pm 0.009$ \\
$3 /-5$ & 1.79 & $1.75 \pm 0.004$ \\
$10 /-5$ & 3.12 & $3.18 \pm 0.004$ \\
$10 / 3$ & 1.74 & $1.71 \pm 0.003$ \\
adults/adults & & \\
$3 /-5$ & 0.70 & $0.77 \pm 0.002$ \\
$10 /-5$ & 0.65 & $0.66 \pm 0.002$ \\
$10 / 3$ & 0.94 & $0.86 \pm 0.003$ \\
\hline
\end{tabular}

not significant $(P>0.05)$ and that there was no conflict with the hypothesis of parallelism when any two lines were compared.

The potency ratios found between the treatments at $-5,3$, and $10^{\circ} \mathrm{C}$ were small and the largest of these ratios indicated that it took the larvae 3.18 times longer to reach $50 \%$ mortality at $10^{\circ} \mathrm{C}$ than at $-5^{\circ} \mathrm{C}$ (Table 2). Larvae were 17 times more susceptible to $-15^{\circ} \mathrm{C}$ than to $-5^{\circ} \mathrm{C}$ (Table 2). Comparison of potency ratios indicated that adult beetles were 3.35 times more tolerant to $-5^{\circ} \mathrm{C}$ than the larvae, but the adults were only 0.73 times as tolerant as the larvae to $10^{\circ} \mathrm{C}$ (Table 2 ).

The tolerance of T. audax adults and larvae to low temperatures contrasts with the low level of tolerance shown by Tribolium castaneum (Herbst) to low temperatures. Evans (1983) found that $T$. castaneum was very susceptible to low temperatures and at $9^{\circ} \mathrm{C}$ had an $\mathrm{LT}_{50}$ of 0.9 weeks for non-acclimatized adults and an $\mathrm{LT}_{50}$ of 3.1 weeks for acclimatized adults. Evans (1987) found that no immature $T$. castaneum survived 13 weeks at $9^{\circ} \mathrm{C}$ and that less than $1 \%$ survived 13 weeks at $13.5^{\circ} \mathrm{C}$. Howe (1962) found that a 2-week exposure to $15^{\circ} \mathrm{C}$ killed all newly hatched $T$. castaneum, but 7-day-old $T$. castaneum larvae were more resistant and showed $80 \%$ survival in the first 2 weeks and $20 \%$ survival at the end of 4 weeks at $15^{\circ} \mathrm{C}$.
$T$. castaneum has been found during surveys for stored products insects in grain residues in granaries in the Prairie provinces, indicating that it survives winter conditions (Liscombe and Watters 1962; Smith and Barker 1987) in spite of its susceptibility to low temperatures. T. audax was found in 20 times more samples than T. castaneum in the Prairie provinces (Smith and Barker 1987), probably because it is well adapted to low temperatures, even without acclimation.

Practical attempts to use cold to eradicate populations of T. audax in grain bulks probably will not be successful if the minimum temperature of the grain is $-5^{\circ} \mathrm{C}$ or higher.

Thanks are due to Y. Bousquet who identified the insects.

Abbott, W.S. 1925. A method of computing the effectiveness of an insecticide. J. Econ. Entomol. 8: 265-267.

Anonymous. 1985. Canada Yearbook. Statistics Canada. $894 \mathrm{pp}$.

Bliss, C.I. 1935. The calculation of the dosagemortality curve. Ann. Appl. Biol. 22: 134-167.

Bousquet, Y. 1990. Beetles associated with stored products in Canada: an identification guide. Res. Branch, Agric. Can. Publ. 1837. 220 pp.

Evans, D.E. 1983. The influence of relative humidity and thermal acclimation on the survival of adult grain beetles in cooled grain. J. Stored Prod. Res. 19: 173-180. 
Evans, D.E. 1987. Survival of immature grain beetles at low temperatures. J. Stored Prod. Res. 23: 79-83.

Finney, D.J. 1971. Probit analysis. Cambridge Univ. Press, London. 333 pp.

Hall, C.W. 1980. Drying and storage of agricultural crops. AVI Publishing Co. Inc., Westport, Connecticut. $381 \mathrm{pp}$.

Howe, R.W. 1962. Observations on the rate of growth and disruption of moulting in the larvae and pupae of Tribolium castaneum (Herbst) (Coleoptera: Tenebrionidae) at sub-threshold temperatures. Entomol. Exp. Appl. 5: 211-222.

Liscombe, E.A.R., and F.L. Watters. 1962. Insect and mite infestation in empty granaries in the Prairie Provinces. Can. Entomol. 94: 433-441.

Loschiavo, S.R. (Editor), D. Abramson, P.S. Barker, J.T. Mills, R.N. Sinha, L.B. Smith, F.L. Watters, and N.D.G. White. 1983. Insects, mites and molds in farm-stored grain in the Prairie Provinces. Agric. Can. Publ. 1595/E. 31 pp.
Madrid, F.J., N.G.D. White, and S.R. Loschiavo. 1990. Insects in stored cereals, and their association with farming practices in southern Manitoba. Can. Entomol. 122: 515-523.

Smith, L.B. 1970. Effects of cold-acclimation on supercooling and survival of the rusty grain beetle, Cryptolestes ferrugineus (Stephens) (Coleoptera: Cucujidae) at subzero temperatures. Can. J. Zool. 48: 853-858.

Smith, L.B., and P.S. Barker. 1987. Distribution of insects found in granary residues in the Canadian Prairies. Can. Entomol. 119: 873-880.

Solomon, M.E. 1951. Control of humidity with potassium hydroxide, sulfuric acid, or other solutions. Bull. Entomol. Res. 42: 543-554.

Watters, F.L. 1963. The cooling of heating grain by transfer during cold weather. J. Econ. Entomol. 56: 215-219. 